\title{
LIBRARY
}

Volume 1 | Issue 2

September 2016

Causing A Racket: Unpacking The Elements Of Cultural Capital In An Assessment Of Urban Noise Control, Live Music, And The Quiet Enjoyment Of Private Property

Sara Ross

York University, Osgoode Hall Law School

Follow this and additional works at: https://opencommons.uconn.edu/tqc

Part of the Law Commons, Music Commons, and the Other Arts and Humanities Commons

Recommended Citation

Ross, Sara. "Causing A Racket: Unpacking The Elements Of Cultural

Capital In An Assessment Of Urban Noise Control, Live Music, And The

Quiet Enjoyment Of Private Property." The Quiet Corner Interdisciplinary

Journal, Vol. 1, Iss. 2, 2016.

Available at: https://opencommons.uconn.edu/tqc/vol1/iss2/8

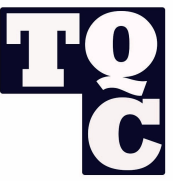




\section{Causing A Racket: Unpacking The Elements Of Cultural Capital In An Assessment Of Urban Noise Control, Live Music, And The Quiet Enjoyment Of Private Property}

\section{Cover Page Footnote}

Sara Ross is a Joseph-Armand Bombardier CGS Doctoral Award holder and Legal Process Instructor at Osgoode Hall Law School, where she is a $\mathrm{PhD}$ candidate. She is an Ontario lawyer, having articled at the Federal Court of Canada under Justice Luc Martineau, and holds an LLM from the University of Ottawa Faculty of Law; a BCL and an LLB with a Major in Commercial Negotiation and Dispute Resolution from the McGill University Faculty of Law; a BA Honours in Anthropology and Archaeology from McGill; and a BA in French Language and Literature from the University of Alberta. Sara would like to thank Professor Angela Cameron for her support and advice on early versions of this paper; the editorial reviewers at the Quiet Corner for their comments and advice; as well as the chair, panelists, and audience of the 2014 Law and Society Association Annual Meeting, where an earlier version of this paper was presented. 


\section{INTRODUCTION}

Noise: "a sound, especially a loud or unpleasant or undesired one" (Canadian Oxford Dictionary).

Since sound is a sensory perception, there is no physical distinction between sound and noise (World Health Organization, "Guidelines for Community Noise" vii). Consequently, noise is defined as unwanted sound, a definition that reveals the negative connotations the use of the word "noise" carries in our society (World Health Organization, "Guidelines for Community Noise" vii). That noise is an annoyance should come as no surprise-its status as an ancient nuisance requiring regulation and control appears as far back as the Roman and Medieval European eras, where some of the dominant civilizations had rules intended to rein in the negative effects of noise, especially nighttime noise that disrupted the sleep of city-dwellers (World Health Organization, "Guidelines for Community Noise" iii). ${ }^{1}$ Today's urban-dwellers encounter noise on a daily and nightly basis (Anthrop 4), ${ }^{2}$ which can have measurable health consequences, ${ }^{3}$ especially as the urban cores of Canadian cities become increasingly louder due to higher population densities that result from the growing numbers of individuals who seek to live downtown (Spalding; Blomley 31; Rose and Villeneuve 146; Lehrer 445-48; August and Walks 276-80; Bourne and Rose 108-109; Lehrer, Keil, and Kipfer 84). This trend towards urban-dwelling can be can be traced to the regeneration efforts of urban planners who aim to revitalize city centers and capitalize on their culture, such as live music venues and live music scenes (Burke and Schmidt 69; Romein and Trip 62; Florida, Rise of the Creative Class 333; Florida Cities and the Creative Class 113; ch 5). ${ }^{4}$ Culture is increasingly seen as a competitive asset for urban economies in this endeavour. ${ }^{5}$

The revitalization efforts involve the creation of new housing developments, such as luxury condominiums in downtown cores, which result in mixed-use environments where urbandwellers share their new neighbourhood with those aforementioned live music venues and live music event attendees. As more people inhabit or purchase private property within these culturally-rich spaces, they are faced with "noise" and the deleterious effects of the elements of

\footnotetext{
${ }^{1}$ Rules regulating noise certainly appear in many other instances throughout history but I do not intend to undertake a historical assessment of noise regulation (see also Spater as well as Montreal (Ville) v 2952-1366 Quebec Inc, 2005 SCC 62, [2005] 3 SCR 141(par 18)).

${ }^{2}$ Donald F Anthrop deems noise pollution to a global issue and the World Health Organization's "Guidelines for Community Noise" treat it in the same manner. While noise may be considered to be a "luxury" problem (World Health Organization, "Guidelines for Community Noise" iii), the perception that noise is a dilemma faced primarily by developed countries ignores the prevalence of noise in marginalized spaces and developing countries.

${ }^{3}$ I will not focus here on the negative effects of noise on health, but see e.g. the for a discussion of health consequences, see the World Health Organization, "Guidelines for Community Noise" (21-36).

${ }^{4}$ Live music fits within Richard Florida's "Bohemian Index" as a factor that attracts "talented and high humancapital individuals" to a city (Grodach and Silver 62). See also Richard Florida's discussion of the "Bohemian Index" (Florida, Rise of the Creative Class 333; Florida, Cities and the Creative Class 113; ch 5.

${ }^{5}$ Arie Romein and Jan Jacob Trip (54) also credit this trend to the emergence of authors such as Richard Florida and his notion of the "creative city". For the Canadian application of these ideas related to the "creative city", see e.g. Deborah Leslie and Norma M Rantisi (83), Tom Hutton and Catherine Murray (143), Silver (249), and Rosemary Coombe.
} 
cultural capital that often drew them to the neighbourhood in the first place ${ }^{6}$ - especially in their interactions with a live music scene, ${ }^{7}$ which can now conflict with other elements of cultural capital that they may value more, such as the quiet enjoyment of their private property (Rief 56). ${ }^{8}$

I examine the tension between and the treatment of these elements of cultural capital, especially within the above-noted dynamic mixed-use spaces, and posit that Canada's current noise control and noise pollution legislation, by-laws, and case law demonstrate a hierarchical protection framework placing greater importance on the "quiet enjoyment of private property" over live music culture, where performances are often the subject of noise complaints. While the elements of cultural capital valued by those who favour the value of quiet enjoyment of private property is well represented throughout legislation, by-laws, and case law, the elements of cultural capital valued by those who favour the value of live music venues and events is comparatively unaddressed.

This article will first describe the expanded lens of cultural capital that informs the theoretical approach applied to the discussion of noise, live music, and property in the city space that will follow. I will then turn to an overview of legislation and by-laws that structure the governance of noise in our cities in order to sketch an outline of the context to which the theoretical approach described below is applied to the subjectivity involved in qualitative versus quantitative noise standards. Finally, alternative perspectives and potential routes towards a better balance in valuating and "tolerating" competing interests in the use of space and sound in the city will be discussed.

\section{CULTURAL CAPITAL}

In order to examine this hierarchical framework, I first turn to Pierre Bourdieu's notion of cultural capital. Cultural capital traditionally discusses family, class position, and the investment made in the cultural capital of youth, with the intent that the return on this investment will reproduce the class position held by the parent (usually within the middle class) in the youth. Particular activities are valued when investing in cultural capital, such as travel, language abilities, high culture, the high arts, and so on. ${ }^{9}$ Cultural capital is not inevitably inherited or innately possessed by middle-class individuals, but it is accrued by amassing particular types of knowledge, abilities, and skills (Yosso 76). This is what I term the "elements" of cultural capital. I view cultural capital as the aggregate value that is derived from these constitutive elements, which carry differential value as some are valued more than others (Bourdieu 114-16, 118-19;

\footnotetext{
${ }^{6}$ These new inhabitants, identified in the relevant literature as gentrifiers, are often the most frequent users of nightlife events such as those involving live music. Ironically, they are usually the most vocal and articulate in objecting to deleterious effects, such as noise (Rief 36; Chatterton and Hollands 64).

${ }^{7}$ For example, complaints related to music comprised $53.3 \%$ of noise complaints made in the City of Ottawa between January 2008 and July 2013 (chart by Leung and Spalding in Spalding). Certainly this figure also includes complaints pertaining to music blaring from a neighbour's apartment.

${ }^{8}$ What is meant by "elements of cultural capital" will be clarified below.

${ }^{9}$ Shane Homan identifies the "high" arts as opera, classical music, and musical theatre (383). Homan also notes the distinction between "entertainment" and "high" cultural forms (384). Based on statistical analysis, Gerry Veenstra identifies traditional "highbrow" cultural practices in Canada with activities such as "listening to CBC radio, attending classical music performances, and visiting art galleries" ("Culture and Class” 100). In contrast, Veenstra identifies "lowbrow" cultural practices in Canada as visiting or attending "parks, historic sites, ... theatrical performances, festivals, or popular music performances" (101).
} 
Veenstra "Culture and Class" 86-87). The differential value ultimately attributed to the aggregate cultural capital of individuals and groups results a hierarchical framework.

As an aggregator of independent elements, cultural capital is a metanarrative, and its hierarchies result in a skewed valuation of different types of culture. ${ }^{10}$ As a metanarrative (Lyotard 31-37), cultural capital furnishes a theoretical framework that seeks to justify and explain the unequal and differential assignment of value of the cultural capital of particular groups or individuals based on their preferences for and practices of different elements of cultural capital (Lyotard 37; "Daring to Deconstruct" 33). In doing so, Bourdieuean cultural capital unfairly minimizes the value of the everyday lived experiences and realities of those who are "at the bottom of society's well" (Bell).

My intention is to deconstruct the metanarrative of cultural capital, distilling its narratives or "elements". This exercise allows me to examine the value placed on each element of cultural capital and the reasons for their different valuations.

\section{A. Critical Race Theory}

The limitations of Bourdieuean cultural capital are characterized by its focus on the white middle- and upper-classes, which necessarily uses white middle-class culture as the standard by which all other iterations of culture are situated and valued (Yosso 76). To overcome the limitations of Bourdieuean cultural capital, I rely on the work of Tara Yosso, who writes from the perspective of critical race theory. Her work allows me to shift the focus of Bourdieuean cultural capital from the values and interests of white middle- and upper-class individuals to those traditionally excluded by this theory (Yosso 77) - those who often voicelessly inhabit the margins and whose interests, due to a plethora of intersecting forms of subordination or stigmatization, do not neatly fit within current noise legislation and by-laws that are mired in subjectivities. ${ }^{11}$ The voicelessness of the margins that critical race theory seeks to bring to the center is essential to address so that all voices may be heard and included within society's dominant discourse that figures in the creation of legislation and by-laws. ${ }^{12}$

\footnotetext{
${ }^{10}$ See also Jean-Francois Lyotard's, The Postmodern Condition: A Report on Knowledge.

${ }^{11}$ Due to the limited scope of this paper, I will not enter into an assessment of the identities and characteristics of those who are not well-represented by current noise legislation and by-laws. I will instead focus on establishing that this group does in fact exist, how and where they have been excluded from the legislation and by-laws, as well as reasons why they have been excluded. However, on intersecting forms of subordination, see e.g. Kimberle Crenshaw’s "Mapping the Margins: Intersectionality, Identity Politics, and Violence Against Women of Colour", and for a discussion of hidden subjectivities and the use and politics of space, see e.g. Patricia L Price's, "At the Crossroads: Critical Race Theory and Critical Geographies of Race" and also Patricia J Williams', The Alchemy of Race and Rights (11).

${ }^{12}$ Regarding the disallowance of entry into a discourse, Yosso refers to the exclusion of racialized individuals from the process of theorizing (69). She refers to Gloria Anzaldúa (xxv), to note how important it is that the excluded and non-dominant occupy this theorizing space and import their own approaches and methodologies in order to transform the "theorizing space" in question. The transformation of this space is what leads to theories that incorporate that which they previously excluded. This applies to discourse that shapes legislation and by-laws that govern our society. Without a voice, how can affected parties have their interests satisfactorily addressed? For a discussion of discriminatory practices within the Canadian legal system, see Carol A Aylward's, Canadian Critical Race Theory: Racism and the Law (40-49). My intention is to show that there are affected parties who are excluded in current noise legislation and by-laws with regard to particular undervalued elements of their cultural capital, which results in a disconnect between current legislation and by-laws and those to whom they apply. In order to
} 
Yosso adds an important dimension to cultural capital. She highlights the shortcomings of traditional iterations of Bourdieuean cultural capital specifically by challenging the hierarchical valuation of cultural capital within the upper- and middle-classes, which, as noted above, excludes marginalized and racialized communities. ${ }^{13}$ Bourdieuean cultural capital traditionally views these communities as "full of cultural poverty disadvantages" because alternative forms of cultural capital are unacknowledged and unrecognized in his framework Yosso 69). Yosso argues that racialized and marginalized communities are in reality characterized by a wealth of cultural capital and goes on to introduce an alternative concept that she terms "community cultural wealth" (70). ${ }^{14}$

While alternative forms of cultural capital and cultural knowledge are greatly valuable to the individuals within these communities or marginalized groups, they do not necessarily carry value, or capital, within the context of dominant society (Yosso 76). ${ }^{15}$ Therefore, the problem with the traditional parameters and definition of cultural capital is that they do not acknowledge community differences that would account for alternative forms of cultural capital. Essentially, Yosso argues for an extension of the boundaries of what constitutes cultural capital and who may have cultural capital. It is from within these extended boundaries of cultural capital that I base my analysis of the hierarchical valuation attributed to elements of cultural capital embodied in the quiet enjoyment of private property versus those embodied by the live music scene.

In applying Yosso's argument, I look to the deconstructed elements of cultural capital that comprise this newly enlarged notion of cultural capital. The cultural capital in communities that have been traditionally attributed a deficit-value cultural capital will necessarily be comprised of different elements than the traditional elements of Bourdieu's notion of cultural capital. Now looking to all of the elements that actually comprise cultural capital, we see how the metanarrative of cultural capital incorrectly imposes a hierarchy of acceptability and value within

ensure that all involved parties are effectively represented and to remedy this voicelessness, the fact of voicelessness and exclusion must first be identified in comparison to groups and the constitutive elements of their cultural capital that is currently well-represented.

${ }^{13}$ See also Pierre Bourdieu and J Passeron's, Reproduction in education, society and culture.

${ }^{14}$ Yosso describes six of these unacknowledged and unrecognized forms of cultural capital that make up community cultural wealth: aspirational capital, familial capital, social capital, navigational capital, resistant capital, and linguistic capital. These six, which are not an exhaustive list, feed into and edify community cultural wealth, which is then translated into cultural capital (Yosso 78).

${ }^{15}$ Elsewhere, Sarah Thornton's work on club cultures (Club Cultures: Music Media and Subcultural Capital addresses alternative forms of cultural capital that exist within subcultures. She refers to cultural capital in this context as "subcultural capital". I agree with Alan O'Connor's critique of Thornton's use of cultural capital (98-99). He views Thornton's application of Bourdieu's notion of cultural capital as an aberration that fails to deploy the notion in the way Bourdieu intended. Yosso avoids this pitfall by arguing for an extended form of cultural capital that includes alternative forms of cultural capital rather than creating an alternative hierarchical framework for these other forms of cultural capital. In passing, it bears mentioning that these notions of alternative cultural capital or subcultural capital criticized by O'Connor may also be described in terms of what Bourdieu calls, "non-certified cultural capital" (Bourdieu 358). This approach is taken up by Lise Bernard in "Le capital culturel non certifié comme mode d'accès aux classes moyennes : L'entregent des agents immobiliers". Bernard discusses the cultural capital deployed by real estate agents as non-certified cultural capital — such as having a way with words or a wellhoned knowledge of how to negotiate social contexts - but which can nonetheless enable an individual to enjoy the same benefits as would be provided by having strong certified cultural capital in terms of enabling a satisfactory placement within the middle and upper classes. 
the elements of cultural capital. Elements not traditionally conceived as forming part of cultural capital, such as live music events that are linked to popular (or "low") culture, are attributed a lesser value, and are thus less likely to benefit from protection.

Applying this methodology, I argue that the exclusion, lack of acknowledgement, and undervaluing of elements that are often within the realm of deficit-valued cultural capital, such as noise-producing live music venues and culture, can be seen through a lack of representation in noise control legislation, by-laws, and existing case law.

\section{B. The Relevance of Deconstructing Cultural Capital: Who is Excluded}

Focusing on the elements of cultural capital permits insight into the everyday lived effects on individuals created by differential valuation within legislation and by-laws of certain elements of cultural capital. ${ }^{16}$ The relevance of asking why these elements of cultural capital are invisible in noise control legislation and by-laws is threefold. First of all, Canadians engage in a wide variety of cultural activities where live musical and cultural performances are highly valued and attended (Veenstra, "Culture and Class"; Veenstra, "Can Taste Illumine Class"; Silver and Clark; Music Canada, "Measuring Live Music in Canada"; Music Canada, "The Next Big Bang"; IFPI and Music Canada, "The Mastering of a Music City"). The lack of protection for noise-creating live music events and venues in noise control legislation, by-laws, and case law reveals an under-representation of the portion of Canadian society that values these elements of cultural capital and an over-representation of the interests of those who do not value these elements of cultural capital as much. ${ }^{17}$

Second of all, live music events and venues represent elements of cultural capital that create a space for individuals to negotiate the transition period between youth and adulthood (Gallan and Gibson). This time period has been extended in the last several decades as individuals start families later in life, which results in a higher number of individuals who are currently in this life phase, leading to changes in consumption practices (Chatterton and Hollands 9-10; Rose and Villeneuve). For these individuals, live music venues and events can provide a space for creativity, a place for community-creating bonds to flourish, and may play an important role in urban liveability as well as the creation of a rich cultural life in the city (Gallan and Glen; Rief; Bavinton 238). Additionally, while some consider this extended youth phase to be accompanied by a greater amount of disposable income since these individuals often choose to remain living with their parents, this is not always true (Chatterton and Hollands 9-10). An extended youth phase also enables more time spent forming a career path through educationtime characterized by lower income periods. It is thus beneficial that live music venues often remain open and accessible to lower-income groups in areas that may otherwise be characterized

\footnotetext{
${ }^{16}$ Rebecca Johnson writes of the importance of remaining aware of justice and inequality within the seemingly trivial events of everyday life (151). See also Aylward who notes the connection between legal concepts and their effects in "real people's lives" (O'Byrne qtd in Aylward 19).

${ }^{17}$ Appropriating theoretical approaches such as cultural capital and applying them to individuals traditionally disempowered by their application can, conversely, have an empowering effect, see e.g. Anzaldúa: "If we have been gagged and disempowered by theories, we can also be loosened and empowered by theories" (xxvi; and qtd in Yosso 70).
} 
by economically inaccessible and higher-end entertainment and consumption venues (Chatterton and Hollands 64-66). ${ }^{18}$

The third reason, as noted previously, is linked to the prior two reasons and adds a layer of complexity to my analysis. As areas commonly associated with nightlife and live music events continue to see increasing gentrification, notably shaped by middle-class professionals and young adults who "seek to live in inner city areas that offer opportunities for entertainment, exotic difference and excitement such as those with a vibrant culture and night-life scene" (Rief 36; Butler), these areas also face the simultaneous consequence of noise complaints voiced by these same gentrifiers who tend to be "the most articulate and vocal in representing their interests against [the] negative side-effects" of these new mixed-use zones within which they have chosen to invest in private property (Rief 36; Chatterton). While these individuals may be seen as wishing to both have their cake and eat it too, the bottom line is that their collective power in voicing their concerns, combined with their relatively high income levels and social status, can ultimately push out and silence noise-creating live music venues (Rief 36; Burke and Schmidt). The absence of legislation and by-laws addressing the interests of live music venues, attendees, and events places these elements of cultural capital in a precarious position with little recourse when faced with displacement. ${ }^{19}$ A palpable example of this type of situation is that of Brisbane, Australia's The Press Club:

A decade ago in Brisbane, a small live music venue named The Press Club sat next to the former head-quarters of the defunct Sun newspaper in Fortitude Valley. The abandoned offices were redeveloped into the Sun Apartments, following planning approval. The new residential complex shared a wall with the existing live music operator ... as well as having a nightclub underneath. Noise complaints ensued, and, under the regulatory frameworks of the time, particularly the noise and liquor law, The Press Club was forced to effectively cease live music performance. With the continued gentrification of Fortitude Valley, other venues faced a similar fate (Burke and Schmidt 68).

\section{A Note on Terminology}

By using the term "live music", I am referring specifically to a context where the music at a venue is the focal point of the event rather than incidental to the event. ${ }^{20}$

\footnotetext{
${ }^{18}$ For a discussion of the role served by club culture in providing youth momentary enjoyment of liberty and luxury while free from adult commitments focused on economic capital, see generally Thornton's book on club cultures (103). Again, I avoid O'Connor's critique of Thornton's application of Bourdieu's notion of cultural capital by discussing the elements of cultural capital and how they are hierarchically valued rather than proposing that attendees of live music events have a discrete cultural capital unique to that subculture (see fn 15 above).

${ }^{19}$ For illuminating discussions on physical exclusion and inclusion of racialized, subordinated, or otherwise stigmatized individuals from the landscape, see generally the critical geographic approach to these issues. For e.g. Price (153).

${ }^{20}$ This distinguishes live music events from the incidental music that characterizes many nightclubs, which is not to say that live music events cannot occur at nightclubs or that nightclubs cannot also be considered live music events. My point is simply that not all nighttime events including music are included within my definition of live music events. See also, Gallan and Gibson, who characterize live music as "amplified, original compositions, with an accessible rather than elitist sensibility. [They] also intend the term to encompass diverse genres such as rock ' $n$ 'roll,
} 
Legislation, by-laws, and case law related to noise control deploy specific terminology to describe the noise/sound emitted from live music venues or during live music events. Musicrelated noise is often referred to with terms such as sound amplification and reproduction, as well as sound equipment, vibrations, and "public address systems".

\section{THE HOW AND WHERE OF EXCLUSION}

\section{$\underline{\text { A. Legislation and } B y-l a w s^{21}}$}

Noise legislation and by-laws have an unfortunate history as tools for distinguishing between "acceptable" and "unacceptable" cultural forms, and thus controlling undesirable premises, their conditions of use, and their attendees (Talbot, "Regulation and Racial Difference" 888; Talbot, Regulating the Night 49, 98-99, 101 , 128; Valverde). These laws and legislation enable control of premises without any need to exercise moral or political judgment about their hours of use and the activities occurring within (Talbot, Regulating the Night 98-99). Since live music creates sound that is potentially perceived as noise and as a nuisance, in areas where live music venues, live music event attendees, and urban-dwellers increasingly co-habit the same space, conflicts surrounding noise can be the main arena where their respective elements of cultural capital collide (Talbot, Regulating the Night 101, 133). Complaints about noise and nuisance can be a way for residents in these mixed-use spaces to voice their dissent against existing live music venues. The use of complaints can also help them to oppose new venues via their role in contesting applications for liquor licenses (Talbot, Regulating the Night 101, 133).

\section{i. The International Context}

At the international level, the World Health Organization [WHO] Noise Guidelines constitute the leading document dealing with noise control. These guidelines suggest three key noise control principles:

(a) The precautionary principle. In all cases, noise should be reduced to the lowest level achievable in a particular situation. Where there is a reasonable possibility that public health will be damaged, action should be taken to protect public health without awaiting full scientific proof.

(b) The polluter pays principle. The full costs associated with noise pollution (including monitoring, management, lowering levels and supervision) should be met by those responsible for the source of noise.

(c) The prevention principle. Action should be taken where possible to reduce noise at the source. Land-use planning should be guided by an

rhythm and blues, metal, and punk music as opposed to classical performance" (191; n 1). Additionally, Burke and Schmidt use the definition: "music performed in public by at least one person in real time, that is, not pre-recorded" (68). As Burke and Schmidt, also delineate, "It is difficult to disentangle this live music, per se, from the broader realm of the night-time economy" (68).

${ }^{21}$ I will not undertake an exhaustive analysis of noise control legislation in Canada due to the scope of this paper.

The examples I consider are intended as illustrations. 
environmental health impact assessment that considers noise as well as other pollutants (World Health Organization, "Guidelines for Community Noise" 66).

Clearly this document prioritizes the significant negative health effects of many types of noise around the globe and is not likely a good starting point for protecting the elements of cultural capital inherent in live music culture. It is nonetheless an instructive exercise to unpack the values embodied and language used in this document since it shapes international awareness of noise as a pollutant.

A strong emphasis is placed on the "polluter pays principle", which adopts a narrow viewpoint that fails to take context into account. For example, where a residential development is placed next to a live music venue, the polluter pays principle does not account for the role of the developer in knowingly constructing residences that will subject the new inhabitants to noise that will compromise the quiet enjoyment of their private property (Burke and Schmidt). The polluter pays principle is a blanket castigation of the source of the perceived noise that also fails to account for first-use rights that may be reasonably anticipated in certain situations. ${ }^{22}$ The third WHO Noise Guidelines - the prevention principle - may be read to address a first-use scenario but suffers from weak wording in comparison to the emphatically worded polluter pays principle. Reference is made to the source of noise and reduction, which is again a blanket castigation of the source of perceived noise. The suggestion of land-use planning guided by an environmental health impact assessment does not clearly encompass important potential prevention mechanisms, such as a contextual assessment of the parties involved and their potentially competing or complimentary values and objectives, ${ }^{23}$ or a developer's responsibility to properly insulate new residences from noise or to be forthcoming regarding the noise levels of the area in question. $^{24}$

\section{ii. The Canadian Context}

Noise control of non-transportation related noise sources in Canada is regulated both provincially and municipally (Stavrakos 46). Canadian cities address noise with a variety of mechanisms that have shifted over time. ${ }^{25}$ Ontario's municipalities, for example, witnessed a shift in provincial legislation from the perception of noise as a matter of public order and nuisance to one of environmental pollution. ${ }^{26}$ Again considering the context of Ontario, municipalities deal with the impacts of noise via two principal means. ${ }^{27}$ The first is through landuse planning, such as the Planning Act, ${ }^{28}$ which is accomplished primarily through official plans

\footnotetext{
${ }^{22}$ Cf Burke and Schmidt (74).

${ }^{23}$ Critique of the policies suggested by the WHO Noise Guidelines is pertinent since they are intended to guide the creation of government policy framework around the world ("Community Noise Guidelines" 66). Greater acknowledgment of context is important to create well-tailored solutions that meet the needs of communities and neighbourhoods and do not result in detrimental results within other elements of the social fabric such as culture.

${ }^{24}$ Cf Burke and Schmidt (74-75); see below at Section III.B

${ }^{25}$ Noise regulation in Ontario first appeared in the Municipal Corporations Act, 1849, 12 Vict, c 81 (also known as the Baldwin Act).

26 This occurred with the passing of the Environmental Protection Act, 1971, SO 1971, c 86; see also Stavrakos (40).

${ }^{27}$ Ibid.

${ }^{28}$ RSO 1990, c P13.
} 
and zoning by-laws that must be consistent with provincial policy statements (Stavrakos 48). The second is through the regulatory powers provided by the Municipal Act, 2001. ${ }^{29}$ In 2006, amendments were made to the Municipal Act, 2001, which extended the authority of municipalities in regulating noise and established permitting and licensing regimes (Stavrakos 40).

In Ontario, the Ministry of the Environment's Model Municipal Noise Control By-law Final Report [Model By-law] was introduced in 1978 as a guide for noise by-laws drafted by municipalities. Its approach to noise control continues to be followed by municipalities in Ontario (Stavrakos 52).

\section{a) Prohibition, Permitting, and Qualitative versus Quantitative Standards}

The Model By-law favoured a prohibition-based approach to noise control rather than a permit or licensing-based approach, which is now replicated in municipal by-laws in Ontario, although permits are nonetheless issued by certain municipalities for public (or special) events. ${ }^{30}$ Also still reflected in current by-laws, the prohibition-based approach of the Model By-law then combined qualitative and quantitative standards that prohibited noises that exceeded these standards (Stavrakos 53). ${ }^{31}$ At the time, the Model By-law recommended qualitative standards for smaller municipalities but suggested combining both quantitative and qualitative approaches would be more appropriate for larger municipalities (Stavrakos 54).

Qualitative noise regulation deals with prohibiting particular types of noise, such as the emission of sound (music) from sound amplification and reproduction devices. Qualitative noise regulation also prohibits types of noise that result in particular effects, such as those which are likely to interfere with an individual's quiet enjoyment of their private property (Stavrakos 53). Quantitative noise regulation centres on the measurement and restriction of noise levels (Stavrakos 53).

\section{B. Subjectivity, Qualitative Regulation, and Case Law}

The qualitative regulation of noise is a core concern for the equitable application of noise control in cities (Stavrakos 54), and it is within qualitative noise standards that the relative valuation of elements of cultural capital is notably apparent. The qualitative assessment of noise in by-laws is inherently subjective both in application and interpretation (Stavrakos 54). This has

\footnotetext{
${ }^{29}$ SO 2001, c 25.

${ }^{30}$ See e.g. City of Ottawa, by-law No 2004-253, Noise By-law (9 June 2004), which provides for an exemption application to use sound reproduction devices for the purposes of a special event. Note that this is the only exemption that can be applied for in the domain of live music in Ottawa. See also e.g. City of Toronto by-law, Municipal Code c 591, Noise (27 August 2010) at s 591-10 [Toronto Noise By-law]; City of London By-law PW-12 Noise By-law (4 May 2009) [London Noise By-law]; City of Hamilton, By-law 03-020, Noise By-law (1 January 2001) [Hamilton Noise By-law].

${ }^{31}$ See e.g. Toronto Noise By-law, supra note 71, London Noise By-law, supra note 71, Hamilton Noise By-law, supra note 71, and Ottawa Noise By-law, supra note 71 for municipalities that combine a qualitative and quantitative assessment of noise. Cf City of Oshawa, By-law 112-82, Noise By-law (2 October 1982) and City of Mississauga , By-law 785-80 amended by By-laws 226-82, 62-92, Nuisance Type Noise By-law (15 October 1980), which are examples of municipalities that follow only the qualitative approach.
} 
led to court challenges of qualitatively focused noised by-laws, which have engaged the Canadian Charter of Rights and Freedoms. ${ }^{32}$

Subjectivity arises in determining the acceptability of the particular type of noise in question, the source of the noise, the time of the day or night the noise occurred, the place or space where the noise occurred, and so on. This subjectivity applies both in terms of enforcing noise control after the noise-causing event as well as in preventative noise management, such as permits and licensing for noise-causing events. Case law is useful for an assessment of differential and inequitable application of noise control in particular contexts and in relation to specific groups of citizens.

Before launching into an examination of subjectivity, it bears noting that courts have nonetheless defended the qualitative and subjective assessment of noise as a necessary mechanism allowing for flexible and adaptable means of responding to specific neighbourhood requirements (Stavrakos 54-55). For example, in Ottawa (City) v Friedman:

[A] certain lack of specificity is required to accommodate the varying needs and preferences of particular groups of residents. An inner city community as opposed to a suburban community, or again, a community of pre-dominantly retired residents as opposed to a community of predominately university students may tolerate a very different standard of what are reasonable nighttime noises. In other words, the nature of the community will become one more factor that this court will consider in determining whether a level of noise at night is reasonable and disturbs the peace and comfort of any person. In light of this desire for flexibility, it cannot be concluded ... that noise by-laws require an objective standard. ${ }^{33}$

\section{i. Subjectivity Based on the Type and Source of Noise}

Since subjectivity plays an important role in the present lower valuation of particular elements of cultural capital such as live music, it is instructive to examine the contexts where subjectivity arises. Since noise is so closely tied to the notion of annoyance, the perception of whether or not a sound is perceived as a noise or music is heavily dependent upon the particular individual placing a noise complaint (Stavrakos 43).

The problem of subjectivity regarding the type of noise is readily apparent in Canadian case law dealing with noise complaints. For example, the Court of Queen's Bench for Saskatchewan in $R v$ Changing Winds Restaurant Inc illustrates the subjective aspect of a noise complaint:

Mr. Dyck ... testified that he preferred country and western music to rock music.

\footnotetext{
${ }^{32}$ Part I of the Constitution Act 1982, being Schedule B to the Canada Act 1982 (UK), 1982, c 11 [Charter]. See e.g. Montreal (Ville) v 2952-1366 Quebec Inc.

${ }^{33} 1998$ CarswellOnt 5974 (WL Can) (Ont Prov Div) at paras 30-33. See also the majority ruling of the Supreme Court of Canada in Montreal (Ville) v 2952-1366 Quebec Inc: "The only acceptable interpretation is one that takes the context into account" (par 33).
} 
Further, he stated that if the music had been higher and he could sing along with the music, any kind of music, he would not have been bothered. The trial judge therefore concluded that what was bothering Mr. Dyck "was not the fact that it was emanating from the Changing Winds, as I understand his statement, was that he couldn't understand it to enjoy it. That being the case, we're dealing with quality of reproduction, quality of sound, and of course, this section - this by-law - does not deal with the quality of sound" (par 5). ${ }^{34}$

Perhaps the most well-known Canadian case dealing with a noise infraction, and the subjective or qualitative analysis of noise/sound, is the Supreme Court of Canada's ruling in Montreal (Ville) v 2952-1366 Quebec Inc. Briefly, this case involved a exotic dancer's club situated on Saint Catherine Street in Montreal that had installed loudspeakers in the main entrance to project music and commentary in order to attract passers-by (par 3). One night at around midnight, a nearby police officer heard the club's music and charged the club with a noise violation under articles 9(1) and 11 of Montreal's Noise By-law. ${ }^{35}$ The club contested the charge on grounds of invalidity of articles 9(1) and 11 but the Municipal Court upheld the charge (par 5).

However, when the club subsequently appealed the Municipal Court's decision to the Superior Court of Quebec, the Superior Court quashed the conviction based on the impugned provisions' restriction of freedom of expression (par 5). While the Quebec Court of Appeal upheld the Superior Court's decision, the Supreme Court eventually overturned the Court of Appeal's decision after interpreting article 9(1) of Montreal's Noise By-law and ultimately finding that the section 2(b) Charter infringement was justified under section 1 of the Charterthus reinstating the original noise violation charge (par 100).

While there is no live music at play in this case, the nature of the source of the noise in terms of venue and contents of the projected sound sharply highlight how subjectivity colours noise control enforcement. Justice Binnie's dissenting opinion is particularly revelatory of this matter. He begins his dissent straightaway by noting the identity of the venue charged with a noise violation: a strip club (par 102). He then turns to the ban on noise produced by sound equipment in article 9(1) of Montreal's Noise By-law and explains that this ban, on face value, could also include sounds such as the residential use of a radio projecting classical music into a peaceful garden, the ringing of a cell phone, and so on (pars 102,174). Yet, he states, due to the

34 (1985) 44 Sask R 148 (QB).

${ }^{35}$ By-law concerning noise, RBCM 1994, c B-3 [Montreal Noise By-law]. Arts 9(1) and 11 read as follows:

9. In addition to the noise referred to in article 8, the following noises, where they can be heard from the outside, are specifically prohibited:

(1) noise produced by sound equipment, whether it is inside a building or installed or used outside;

11. No noise specifically prohibited under articles 9 or 10 may be produced, whether or not it affects an inhabited place. 
nature, purpose, and source of the noise, it is highly unlikely that these other noises/sounds would ultimately result in the finding of a noise violation (par 118).

\section{ii. Subjectivity Based on the Time of Noise}

The time of the day that noise occurs is a determinative factor in determining how it will be treated, especially in the context of live music events since they generally occur in the evening or at night. This particular component of a qualitative-based approach to noise regulation has the greatest effect on the subjective view of the acceptability of live music venues and events. For this section of the paper, it is helpful to include live music events within the more general nighttime economy due to the abundance of literature on the subject.

The fact that music/noise occurs during the nighttime hours is usually what leads to noise complaints in the first place. As mentioned in the introduction to this paper, the regulation of noise has always been more concerned with noise at night since its most detrimental effects are usually considered to be those that affect sleep (World Health Organization, "Guidelines for Community Noise" iii). As such, it is within the context of the night that there is the greatest observable tension between the elements of cultural capital embodied by live music culture and the elements represented by the quiet enjoyment of private property.

The nighttime economy presents municipalities with the same dilemma faced in urban regeneration strategies that seek to draw young, middle-class professionals to the urban core with promises of a vibrant and edgy culture but then must simultaneously manage the vocal protests of this same group in dealing with the deleterious effects of dwelling in the urban core (Rief 36). On the one hand, a vibrant nighttime economy provides a city with attractive economic benefits but, on the other hand, increases regulatory concerns related to noise and nuisance (Talbot, "Regulation and Racial Difference" 887; Rief 55). Ultimately, "there is a strong notion in public and legal discourses of the current decade that the nighttime economy is a source of 'pollution' and social dysfunction in need of control and "cultural engineering'" (Rief 42). This pervasive opinion is particularly problematic since those who consume nightlife are largely disregarded in devising governance strategies, leaving them voiceless (Chatterton and Hollands 64). ${ }^{36}$ Since consumers within the nighttime economy tend to be young people, this exemplifies a deficit valuation of elements of cultural capital that characterize the particular demographic they belong to, which is particularly relevant in the context of live music since the focal point that music enjoyment carries within this scene may prove a relative sanctuary compared to other nightlife options (Chatterton and Hollands 64-66; Gallan and Gibson 177).

\section{Unfortunate Bedfellows: Live Music and Liquor Legislation}

The time/space that live music events share with nighttime entertainment and leisure mean that the interests of live music culture must frequently be negotiated within the terms of alcohol consumption and control. Since licensing is often used to manage urban order and the acceptable use of space (Hubbard, Matthews, and Scoular; Valverde), it is no surprise that the

\footnotetext{
36 This includes disregard both in addressing or solving problems consumers face as well as defining these problems in the first place (Chatterton and Hollands 64-66).
} 
granting of liquor permits takes into account whether or not it is anticipated that live music (and noise) will accompany the liquor license if granted.

The balance that must be struck between the interests of live music venues and the surrounding communities is clearly exemplified through public interest hearings that occur as part of applications for a liquor license. Citing a prior decision, the Ontario Alcohol and Gaming Commission writes:

Public interest hearings often raise very difficult issues which require a delicate balance of the interest of those who live in the community with those who would earn their living there. Under the Liquor Licence Act, there is a qualified right to a liquor licence, subject to the considerations of the "public interest". The Act thus recognizes the very real impact that a licensed premises may have on the surrounding community, and the local residents are provided with a forum in which their concerns can be voiced. $^{37}$

While on the surface this may seem to strike an equal balance between live music culture and the quiet enjoyment of private property, the reality is that the interests of the surrounding community are often favoured-whether this occurs through the specific wording of legislation, ${ }^{38}$ or through the aggregate power of the surrounding community's complaints compared to the live music venue and attendees, who will not often be aware of the public hearing let alone go out of their way to defend a venue at the hearing (Rief 36).

It thus becomes apparent that the regulation of liquor through the provision of liquor licensing is another regulatory mechanism in controlling the availability and viability of music events held by venues at night. When a surrounding community asserts that the quiet enjoyment

${ }^{37}$ Cue's Whole 9 Yards (Re), 2007 CanLII 6216, citing Juke Box Live (unreported).

${ }^{38}$ See e.g. Triple Gates Investment Ltd (Re), 2008 NSUARB 148: The license applicant applied for a lounge license in order to serve alcohol and remain open after 9pm. The application also included a proposal to offer live and amplified entertainment consisting of a "Lebanese singer and belly dancer". Since the Liquor Control Act (RSNS 1989, c 260 [Act]) in place at the time required that a public hearing be held, which resulted in petitions from two nearby condominium complexes that opposed the application. In order for the application to succeed under the Act (specifically the Liquor Licensing Regulations, NS Reg 365/2007) in place at the time, s 8(b) required that "the Review Board [be] satisfied that operating the licensed premises will not interfere in any way with the quiet enjoyment of neighbouring properties" [emphasis added]. The license applicant testified regarding his "passion of bringing Lebanese culture to Canada [and] providing authentic Lebanese food" (par 8). Individuals from the condominium complexes who opposed the application were concerned with matters such as the change in clientele that the license would bring and how it would affect their quiet enjoyment (par 15), that the amplified music to accompany the lounge license would fail to add to the comfort and enjoyment of the condominium residents (par 18), and that the right of the condominium residents to quiet enjoyment would be greatly affected (pars 19-20). Evidence was adduced on the part of the license applicant demonstrating that noise pollution would be controlled (par 26). Ultimately, however, the license applicant could not overcome the wording of the Act which required that operation of the licensed premises be judged prospectively to not interfere in any way with the quiet enjoyment of the neighbouring properties (pars 30-39). NB: The specific language of the regulation mentioned above (s 8(b)) was amended subsequent to 13 January 2012 by removing the strict statement that the operation of the licensed premise "will not interfere in any way". It now instead simply states that the licensed premise "will not interfere". As a result, the standard that a venue must meet no longer seems entirely impossible, and now just seems very difficult to satisfy. 
of their private property is or may be affected, more weight is often attributed to their interests than a venue's music events at night. And when the provision of liquor licensing to a venue is successfully deterred, a valuation has occurred where the elements of cultural capital of one group are being attributed a higher value than the elements of cultural capital valued by the other group.

\section{Notions of Tolerance and the Space and Place of Noise}

It must be kept in mind that the notion of quiet enjoyment of private property is also a subjective determination that depends on the space and place within which it is expected. For example, as stated by Nova Scotia Utility and Review Board:

Further, the Board considers that quiet enjoyment can be a concept which is measured in degrees. The level of quiet enjoyment that can be expected in a rural setting, or on the outskirts of a small town, may be quite different than that which can be reasonably expected in a vibrant urban environment such as downtown Halifax (55). ${ }^{39}$

Especially with increasing levels of ambient noise levels in urban centers, and the increasing popularity of downtown dwelling with a view to experiencing a vibrant cultural environment, expectations for the quiet enjoyment of private property must be properly managed (Spalding). A certain level of tolerance is required of urban-dwellers. ${ }^{40}$ But, as stated by the Supreme Court of Canada, "[t]olerance of noise varies from one individual to another" (par 48). ${ }^{41}$

"Tolerance" is in fact a key ingredient in the "creative city", the concept popularized by Richard Florida that led so many urban planners to jump onto the bandwagon of urban regeneration strategies - strategies that have, more often than not, resulted in the gentrification of culturally-rich urban cores (Romein and Trip 54; Rief 55; Florida, Cities 129; ch 6). As explained by Rosemary Coombe, the creative city, and its accompanying economy and industries, value "creative people". ${ }^{42}$ In selling the "urban cultural experience", cities and their urban planners seek to attract creative people to urban cores by commodifying not only the space (restored old buildings or new constructions replacing the old) but also the individuals who traditionally inhabit the space, which Coombe describes as "those who bear cultural difference, be they artists, homosexuals, or 'ethnic' minorities" (42-43). Yet while cities have been busy with these urban regeneration and commodification projects, the ingredient of "tolerance" in managing these new gentrified and mixed-use spaces is largely unaddressed in noise legislation and by-laws. This is increasingly problematic not only for those individuals and venues receiving the short end of the stick and who are not being tolerated, but it is also problematic for the

\footnotetext{
${ }^{39}$ The Bitter End and Mosaic, 2011 NSUARB 86 (available on CanLII).

${ }^{40}$ For example, regarding the management of resident expectations and live music concerts in Halifax, City Councillor Sue Uteck has stated that "residents all over the municipality are asked to put up with noise at certain times of the year as part of the price they pay for living in a vibrant city" (Boutilier).

${ }^{41}$ Montreal (Ville) v 2952-1366 Quebec Inc.

${ }^{42}$ In legal terms, creative industries can be identified as those that produce copyrights, patents, designs, and trademarks (Coombe 43). See also generally John Howkins's The Creative Economy. In essence, creative industries are defined by their creative content (Florida, Rise of the Creative Class 46-47). "Creative people" are those who work in the creative industries.
} 
viability of these newly developed spaces. Coombe notes that an important element in maintaining the creative draw of these culturally rich centers is social tolerance, respect for diversity, and cultural dialogue (42-43).

Interestingly, however, "tolerance" does make an appearance in the Civil Code of Quebec [CCQ] at article 976 : "Neighbours shall suffer the normal neighbourhood annoyances that are not beyond the limit of tolerance they owe each other, according to the nature or location of their land or local custom." In unpacking this provision, it is difficult not to notice that the CCQ seems to hint at a neighbour's burden to tolerate a certain extent of annoyance within a neighbourhood, correlative to the kind of neighbourhood they choose to inhabit. The CCQ is careful to note the location and context of the annoyance as a factor to consider in tolerating an annoyance. The mention of "local custom" bears noting as well since this may be particularly relevant in addressing situations of gentrification where pre-existing live music venues, or live music customs, existed before the urban regeneration projects that led to new housing developments and mixed-use zones. In these situations, greater tolerance would certainly be important.

\section{WHAT CAN BE DONE?}

\section{A. A Seed for Change in Legal Decisions}

What is fundamentally remiss in the Canadian context, is a failure to effectively balance the valuation of elements of cultural capital embodied in the live music scene with the elements of cultural capital that comprise an individual's quiet enjoyment of private property. As I have demonstrated, this imbalance is characterized by the appearance of the notion of quiet enjoyment of private property in legislation, by-laws, and case law, but the same cannot be said for the cultural value of live music, which only appears in relation to concerns linked to noise and nuisance. Much of this is traceable to the evaluation of noise complaints via a qualitative assessment that is inherently subjective.

Justice Binnie's dissenting opinion in Montreal (Ville) v 2952-1366 Quebec Inc, addresses this subjective component in assessing the source and type of noise in determining "acceptable" noise versus "unacceptable" noise-that noise produced by sound equipment emitted from a strip club onto Saint Catherine's Street at night would receive differential treatment from the sounds of Mozart produced by sound equipment emitted from a kitchen window into a garden (pars 118-20). Justice Binnie suggests that these two situations could theoretically both be "caught" by noise control legislation, yet it would be highly unlikely that a passing police officer would apprehend the Mozart-projecting perpetrator. Certainly Justice Binnie's dissenting opinion does not carry precedential power, but it is nonetheless the seed for new thought and future legal decisions moving forward.

\section{B. Case Study: The Fortitude Valley Entertainment Precinct}

I now return to the example of the former industrial suburb Fortitude Valley in Brisbane, Australia, which demonstrates what I view as a better balance in dealing with live music venues and surrounding communities. Brisbane did not always support live music, as you may recall from the unfortunate example of The Press Club described at the beginning of this paper (Burke and Schmidt 73). After The Press Club affair of 1999, Brisbane's once dismal record began to 
improve. In order to protect the rich and diverse live music scene in Fortitude Valley from encroaching urban redevelopment due to urban renewal initiatives, a campaign lobbying the government was initiated. The government eventually agreed to work with the local music industry in order to accommodate the area's live music consumers and live music venue operators as well as the area's new residential housing developers (Burke and Schmidt 73). Noise pollution problems were indeed a concern as gentrification took place and apartments were built next door to clubs and pubs that had inhabited the area first. As opposed to prior approaches, the government now deployed greater collaboration and cooperation between the involved parties, which ultimately resulted in a unique place-based approach creating a designated "Entertainment Precinct", replete with altered liquor and planning laws and a distinct manner of addressing noise emissions (Burke and Schmidt 73).

Of particular relevance, the Entertainment Precinct was governed by a quantitative standard for noise emissions rather than a qualitative and subjective standard. This quantitative standard set allowable noise levels from within venues instead of basing levels on noise heard inside dwellings situated nearby (Burke and Schmidt 74). Accompanying the standards required of live music venues, new housing developments also had to adhere to a set of standards requiring them to invest in noise reduction measures, such as high levels of noise insulation, that lowered noise in all residences by a specified amount (Burke and Schmidt 74).

This arrangement is admirable in its equitable treatment of the involved parties. Rather than allowing live music venues to be pushed out by new development, or simply establishing "first-use rights" for venues in existence before new residential developments, the Entertainment Precinct protects both live music venues and enables housing developments for those who wish to live in the area (Burke and Schmidt 74). There is an element of "full-disclosure" here as well where prospective property purchasers and new residents are made aware of the specific noise levels that can be expected at different times of the day, night, and week (Burke and Schmidt 75). The Entertainment Precinct even makes available a "Valley Sound Machine" where prospective purchasers or renters can virtually experience anticipated noise levels. ${ }^{43}$ There are also other non-noise-related mechanisms that have been implemented in the Entertainment Precinct in order to better the experience of the nightlife consumer in Fortitude Valley (Burke and Schmidt 75-76).

A cautionary criticism provided by Schmidt and Burke, however, is that the Fortitude Valley Entertainment Precinct model may not be applicable to cities larger than Brisbane (Burke and Schmidt 76-77). It nonetheless bears noting that, from a Canadian perspective, Brisbane is not that small a city. With a population of approximately 2.2 million it is about the size of metropolitan Vancouver, Canada's third-largest city. Brisbane is also larger than the City of Montreal, not including its metropolitan areas, as well as being only slightly smaller than the City of Toronto under the same terms.

\section{Revamping Permitting and Licensing Processes}

In the Canadian context, another possibility may be to better employ permitting processes that are currently underutilized by municipalities in Ontario (Stavrakos 53, 58). In applying this

\footnotetext{
${ }^{43}$ This sound machine can be accessed through the Brisbane City Council website: http://www.brisbane.qld.gov.au/.
} 
to a greater valuation of live music venues and events as elements of cultural capital, this may be a worthy route to explore. Currently in cities such as Ottawa, exemptions from the Noise By-law may be provided for the use of sound reproduction devices in the case of special events. ${ }^{44}$ The provision of similar exemptions could be widened to include live music events that occur in permanent venues. ${ }^{45}$ It would be preferable if improved permit and licensing regimes that could potentially apply specifically to live music venues were focused on noise and sound amplification and reproduction rather than embedded within liquor permits. By placing the noise/sound control of venues exhibiting live music within liquor legislation, liquor by-laws, and liquor permits, there is an unnecessary negative link between concerns with alcohol and elements of cultural capital embodied by live music events.

Licensing regimes may also be better utilized in order to create special business licenses for venues that operate at night and seek to present music that may lead to noise complaints (Stavrakos 60). While increased focus on business licenses may be seen as an additional mechanism for the enforcement of noise control, a properly engineered licensing regime bearing in mind the interests of live music could also provide greater protection to live music venues and, generally, greater attention to addressing the tension between live music event attendees and the surrounding community's concerns with quiet enjoyment of private property. ${ }^{46}$

\section{CONCLUSION}

At some point or another, most of us have encountered the concept of a noise complaint - whether we placed the complaint, the complaint was made about us, or we were simply made aware of a context within which it occurred. Seemingly a trivial detail to most of us, it is often these unimportant minutiae of everyday life that belie society's underlying systemic biases, injustices, and exclusionary frameworks (Johnson 151). In order to identify these systemic problems and attempt to remedy them, it is important to pay attention and question these small aspects of everyday life. While we may not be affected personally, there is certainly someone out there who suffers the effects. And even while we may be able to shrug off the effects of an inconsequential injustice and ignore a subtle sign of systemic marginalization or exclusionary practice, we are also ignoring our good fortune in experiencing only this subtle effect.

I have drawn on Bourdieu's notion of cultural capital, expanded what is traditionally considered to be cultural capital through Yosso's reformulation of cultural capital that includes alternative forms of culture capital, and I have teased cultural capital apart into its constitutive elements. The purpose of considering the constitutive elements of cultural capital, such as the enjoyment and appreciation of live music events and the quiet enjoyment of private property, is to be able to see the relative value they are attributed by legislation, by-laws, and case law, notably within Canada and Ontario.

\footnotetext{
${ }^{44}$ Although the parameters of these exemptions impose strict time restrictions both in terms of duration of the entire event as well as daily limitations on when permissible sound reproduction and amplification may occur (see the Ottawa Noise By-law, supra note 71).

${ }^{45}$ The logistics of this suggestion will have to be explored in greater detail elsewhere.

46 The City of Edmonton, for example, has a Business License Bylaw (City of Edmonton, by-law 13138, Business License Bylaw (29 August 2002)) that is along these lines, although the pros and cons and successes and failures of Edmonton as a case study is beyond the scope of this paper.
} 
A hierarchy is revealed where those who value elements such as live music are far less represented than those who value the quiet enjoyment of private property. These values characterize different groups within society, or maybe even different aspects of ourselves, and represent differential treatment. Justice Binnie's resounding dissent in Montreal (Ville) v 29521366 Quebec Inc gestures towards a subjective qualitative assessment of noise that clearly castigates certain sources and types of noise over others. The lack of protection for live music in current by-laws and legislation, in comparison to the healthy representation of the quiet enjoyment of private property, can result in the sudden gutting of a rich cultural center-as exemplified in 1999 in Brisbane with the end of live music at The Press Club that began to spread to the rest of Fortitude Valley before the conscientious citizens took action and pressured the local and state government to intervene. We must also jealously guard our cultural treasures and equally value each other's preferred elements of cultural capital. As the number of gentrifiers grows, and the number of youth who elongate their period of early adult development increases, the clashes between the dominant and the marginalized within the context of mixed-use space will only intensify, unless something is done to resolve this tension.

\section{WORKS CITED}

Anthrop, Donald F. "The Noise Crisis." Noise Pollution and the Law. Ed. James L. Hildebrand. Buffalo: William S, Hein \& Co, 1970. 3-10. Print.

Anzaldúa, Gloria. Haciendo Caras/Making Face, Making Soul: Creative and Critical Perspectives by Women of Color. San Francisco: Aunt Lute Press, 1990. Print.

August, Martine and Alan Walks. "From Social Mix to Political Marginalisation? The Redevelopment of Toronto's Public Housing and the Dilution of Tenant Organisational Power." Mixed Communities: Gentrification by Stealth?. Ed. Gary Bridge, Tim Butler, and Loretta Lees. Bristol: Policy Press, 2012. 273-98. Print.

Aylward, Carol A. Canadian Critical Race Theory: Racism and the Law. Halifax: Fernwood Publishing, 1999. Print.

Bavinton, Nathaniel. "Putting Leisure to Work: City Image and Representations of Nightlife." Journal of Policy Research in Tourism, Leisure \& Events 2.3 (2010): 236-50. Print.

Bell, Derrick A. Faces at the Bottom of the Well: The Permanence of Racism. New York: Basic Books, 1996. Print.

Bernard, Lise. "Le capital culturel non certifié comme mode d'accès aux classes moyennes : L'entregent des agents immobiliers." Actes de la recherche en sciences sociales 1 (2012): 68-85. Print.

Blomley, Nicholas. Unsettling the City: Urban Land and the Politics of Property. New York: Routledge, 2004. Print.

Bourdieu, Pierre and J Passeron. Reproduction in Education, Society and Culture. London: Sage, 1977. Print.

Bourdieu, Pierre. Distinction: A Social Critique of the Judgement of Taste. Trans. Richard Nice. London, UK: Routledge \& Kegan Paul, 1984. Print.

Bourne, Larry S. and Damaris Rose. "The Changing Face of Canada: The Uneven Geographies of Population and Social Change." Canadian Geographer 45.1 (2001): 105-119. Print.

Boutilier, Alex. "Common Concert Gets Pass on Noise Bylaw." Metro Halifax 22 June 2010. Web. 30 Oct. 2015.

Burke, Matthew and Amy Schmidt. "How Should We Plan and Regulate Live Music in 
Australian Cities? Learnings from Brisbane." Australian Planner 50.1 (2013): 68-78. Print.

Butler, Tim. "Gentrification." Changing Cities: Rethinking Urban Competitiveness, Cohesion and Governance. Ed. N. Buck et al. Basingstoke, UK: Palgrave Macmillan, 2005. Print.

By-law concerning noise, RBCM 1994, c B-3.

Canadian Charter of Rights and Freedoms, Part I of the Constitution Act, 1982, being Schedule B to the Canada Act 1982 (UK), 1982, c 11.

Chatterton, Paul. "Governing Nightlife: Profit, Fun and (Dis)order in the Contemporary City." Entertainment Law 1.2 (2002): 23-49. Print.

Chatterton, Paul and Robert Hollands. Urban Nightscapes: Youth Cultures, Pleasure Spaces and Corporate Power, London, UK: Routledge, 2003. Print.

City of Edmonton, by-law 13138, Business License Bylaw (29 August 2002).

City of Ottawa, by-law No 2004-253, Noise By-law (9 June 2004).

Civil Code of Quebec.

Cohen, Sara. Decline. Renewal and the City in Popular Music Culture: Beyond the Beatles. Hampshire, UK: Ashgate, 2007. Print.

Cole, Daniel H. Pollution \& Property: Comparing Ownership Institutions for Environmental Protection. Cambridge UK: Cambridge University Press, 2002. Print.

Coombe, Rosemary J. "Contingent Articulations: A Critical Cultural Studies of Law." Law in the Domains of Culture. Ed. A Sarat and T Kearns. Ann Arbor: University of Michigan Press, 1998. 21-64. Print.

---. "Legal Claims to Culture in and Against the Market: Neoliberalism and the Global Proliferation of Meaningful Difference." Law, Culture and the Humanities 1(2005) 35-52. Print.

Crenshaw, Kimberle. "Mapping the Margins: Intersectionality, Identity Politics, and Violence Against Women of Colour." Stanford Law Review 43 (1991): 1241-1300. Print.

Cue's Whole 9 Yards (Re), 2007 CanLII 6216 (ON AGC).

Florida, Richard. Cities and the Creative Class. New York: Routledge, 2005. Print.

---. The Flight of the Creative Class. New York: HarperBusiness, 2005. Print.

---. The Rise of the Creative Class: And How It's Transforming Work, Leisure Community and Everyday Life. New York: Basic Books, 2002. Print.

Gallan, Ben \& Chris Gibson. "Mild-Mannered Bistro by Day, Eclectic Freak-Land at Night: Memories of an Australian Music Venue." Journal of Australian Studies 37.2 (2013): 174-93. Print.

Gelder, Ken. Subcultures: Cultural Histories and Social Practice. London, UK: Routledge, 2007. Print.

Grodach, Carl. "City Image and the Politics of Music Policy in the 'Live Music Capital of the World'." The Politics of Urban Cultural Policy: Global Perspectives. Ed. Carl Grodach and Daniel Silver. (London, UK: Routledge, 2013) 98-109. Print.

Homan, Shane. "From Coombs to Crean: Popular Music and Cultural Policy in Australia." International Journal of Cultural Policy 19.3 (2013): 382-98. Print.

Howkins, John. The Creative Economy. New York: Allen Lane, 1991. Print.

Hubbard, Phil, Roger Matthews, and Jane Scoular. "Legal Geographies--Controlling Sexually Oriented Businesses: Law, Licensing, and the Geographies of a Controversial Land Use." Urban Geography 30.2 (2009): 185. Print.

Hutton, Tom and Catherine Murray, "The New Cultural Economy and its Discontents: 
Governance Innovation and Policy Disjuncture in Vancouver." The Politics of Urban Cultural Policy: Global Perspectives. Ed. Carl Grodach and Daniel Silver. London, UK: Routledge, 2013. 141-53. Print.

Jenkins, Barbara. "Cultural Spending in Ontario, Canada: Trends in Public and Private Funding." International Journal of Cultural Policy 15.3 (2009): 329-42. Print.

Johnson, Rebecca. "Bars, Breasts, Babies: Justice L'Heureux-Dube and the Boundaries of Belonging." Adding Feminism to the Law: The Contributions of Madame Justice L'Heureux-Dube. Ed. Elizabeth Sheehy. Toronto: Irwin Law, 2004. 143-57. Print.

Lehrer, Ute. 'Re-Placing Canadian Cities: The Challenge of Landscapes of 'Desire' and 'Despair'." Canadian Cities in Transition: Local Through Global Perspectives. Ed. Trudi Bunting and Pierre Filion. 3d ed. Toronto: Oxford University Press, 2006. 438. Print.

Lehrer, Ute, Roger Keil, and Stefan Kipfer. "Reurbanization in Toronto: Condominium Boom and Social Housing Revitalization.” The Planning Review 46.180 (2010): 81-90. Print.

Leslie, Deborah and Norma M Rantisi. "Creativity and Urban Regeneration: The Role of La Tohu and the Cirque du Soleil in the Saint-Michel Neighborhood in Montreal." The Politics of Urban Cultural Policy: Global Perspectives. Ed. Carl Grodach and Daniel Silver. London, UK: Routledge, 2013. 83-97. Print.

Liquor Control Act, RSNS 1989, c 260.

Liquor Licensing Regulations, NS Reg 365/2007 (current version).

Liquor Licensing Regulations, NS Reg 365/2007 (version in force until 13 January 2012).

Lyotard, Jean-Francois. The Postmodern Condition: A Report on Knowledge. Trans. Geoff Bennington and Brian Massumi. Minneapolis: University of Minnesota Press, 1984.

Print.

Mommaas, Hans. "Cultural Clusters and the Post-Industrial City: Towards the Remapping of Urban Cultural Policy." Urban Studies 41.3 (2004): 507-32. Print.

Montreal (Ville) v 2952-1366 Québec inc, 2005 SCC 62, [2005] 3 SCR 141.

Municipal Corporations Act, 1849, 12 Vict, c 81.

O'Byrne, Shannon. "Legal Criticism as Storytelling." Ottawa Law Review 23.3 (1991): 487-503. Print.

O'Connor, Alan. "The Eagle and the Hummingbird: Questions for Cultural Studies. " Pretexts: Literary and Cultural Studies 10.1 (2001): 93-118. Print

Ontario Ministry of the Environment. "Model Municipal Noise Control By-law: Final Report." Aug. 1978. Print.

Ottawa (City) v Friedman, 1998 CarswellOnt 5974 (WL Can) (Ont Prov Div).

Price, Patricia L. "At the Crossroads: Critical Race Theory and Critical Geographies of Race." Progress in Human Geography 34.2 (2010): 147-74.

Pun, Gregory S and Margaret I Hall. The Law of Nuisance in Canada. Markham: LexisNexis, 2010. Print.

$R v$ Changing Winds Restaurant Inc, (1985) 44 Sask R 148 (QB).

Rief, Silvia. Club Cultures: Boundaries, Identities, and Otherness. New York: Routledge, 2009. Print.

Romein, Arie and Jan Jacob Trip. "Notes of Discord: Urban Cultural Policy in the Confrontational City." The Politics of Urban Cultural Policy: Global Perspectives. Ed. Carl Grodach and Daniel Silver. London, UK: Routledge, 2013. 54-68. Print.

Rose, Damaris and Paul Villeneuve. "Life Stages, Living Arrangements, and Lifestyles." 
Canadian Cities in Transition: Local Through Global Perspectives. Ed. Trudi Bunting and Pierre Filion, 3d ed. Toronto: Oxford University Press, 2006. 138. Print.

Scott, Michael. "Cultural Entrepreneurs, Cultural Entrepreneurship: Music Producers, Mobilising and Converting Bourdieu's Alternative Capitals." Poetics 40.3 (2012): 237-55. Print.

Silver, Daniel. "Local Politics in the Creative City: The Case of Toronto." The Politics of Urban Cultural Policy: Global Perspectives. Ed. Carl Grodach and Daniel Silver. London, UK: Routledge, 2013. 249-63. Print.

Silver, Daniel and Terry Nichols Clark. "Buzz as an Urban Resource." Canadian Journal of Sociology 38.1 (2013): 1-31.

Spalding, Derek. "City of Noise: What's That You Say? Ottawa is Getting Louder." Ottawa Citizen 18 Oct. 2013. Web. 30 Oct. 2015.

Spater, George A. "Noise and the Law." Noise Pollution and the Law. Ed. James L. Hildebrand. Buffalo: William S Hein \& Co, 1970. 21. Print.

Staff (Editorial). "Daring to Deconstruct: The Rise of Postmodernism in Theory." Harvard International Review 31.4 (2010). Web. 30 Oct. 2015.

Stavrakos, Konstantine J. "Municipal Noise By-laws: How Municipalities May Rise to the Challenge of Regulating Noise as an Environmental Pollutant." Municipal and Planning Law Reports 86.4 (2011): 40. Print.

Stevenson, Deborah. "Night-Moves: Cultural Precincts and the 24-Hour City." On the Bounce: The Challenge of the Night-Time Economy. Ed. David Rowe and Nathaniel Bavinton. New South Wales: Cultural Industries and Practices Research Centre (CIPS), 2004. 1215. Web. 30 Oct. 2015.

Talbot, Deborah. "Regulation and Racial Differentiation in the Construction of Night-time Economies: A London Case Study." Urban Studies 41.4 (2004): 887-901.

---. Regulating the Night: Race, Culture and Exclusion in the Making of the Night-time Economy. (Hampshire: Ashgate, 2007. Print.

The Bitter End and Mosaic, 2011 NSUARB 86 (available on CanLII)

Thornton, Sarah. Club Cultures: Music Media and Subcultural Capital. Cambridge, UK: Polity Press, 1995. Print.

Triple Gates Investment Ltd (Re), 2008 NSUARB 148.

Valverde, Mariana. "Taking Land Use Seriously: Toward an Ontology of Municipal Law." Law, Text, Culture 9.1 (2005): 34-58. Print.

Veenstra, Gerry. "Culture and Class in Canada." Canadian Journal of Sociology 35.1 (2010): 83111. Print.

Veenstra, Gerry. "Can Taste Illumine Class? Cultural Knowledge and Forms of Inequality." Canadian Journal of Sociology 30.3 (2005): 247-79. Print.

Williams, Patricia J. The Alchemy of Race and Rights. Cambridge, MA: Harvard University Press, 1991. Print.

World Health Organization. Guidelines for Community Noise (Geneva: World Health Organization. Ed. Bergland Birgitta, Thomas Lindvall, and Dietrich H. Schwela. Geneva: World Health Organization, 1999. Web. 30 Oct. 2015.

Yosso, Tara J. "Whose Culture has Capital? A Critical Race Theory Discussion of Community and Cultural wealth." Race Ethnicity and Education 8.1 (2005): 69-91. Print. 


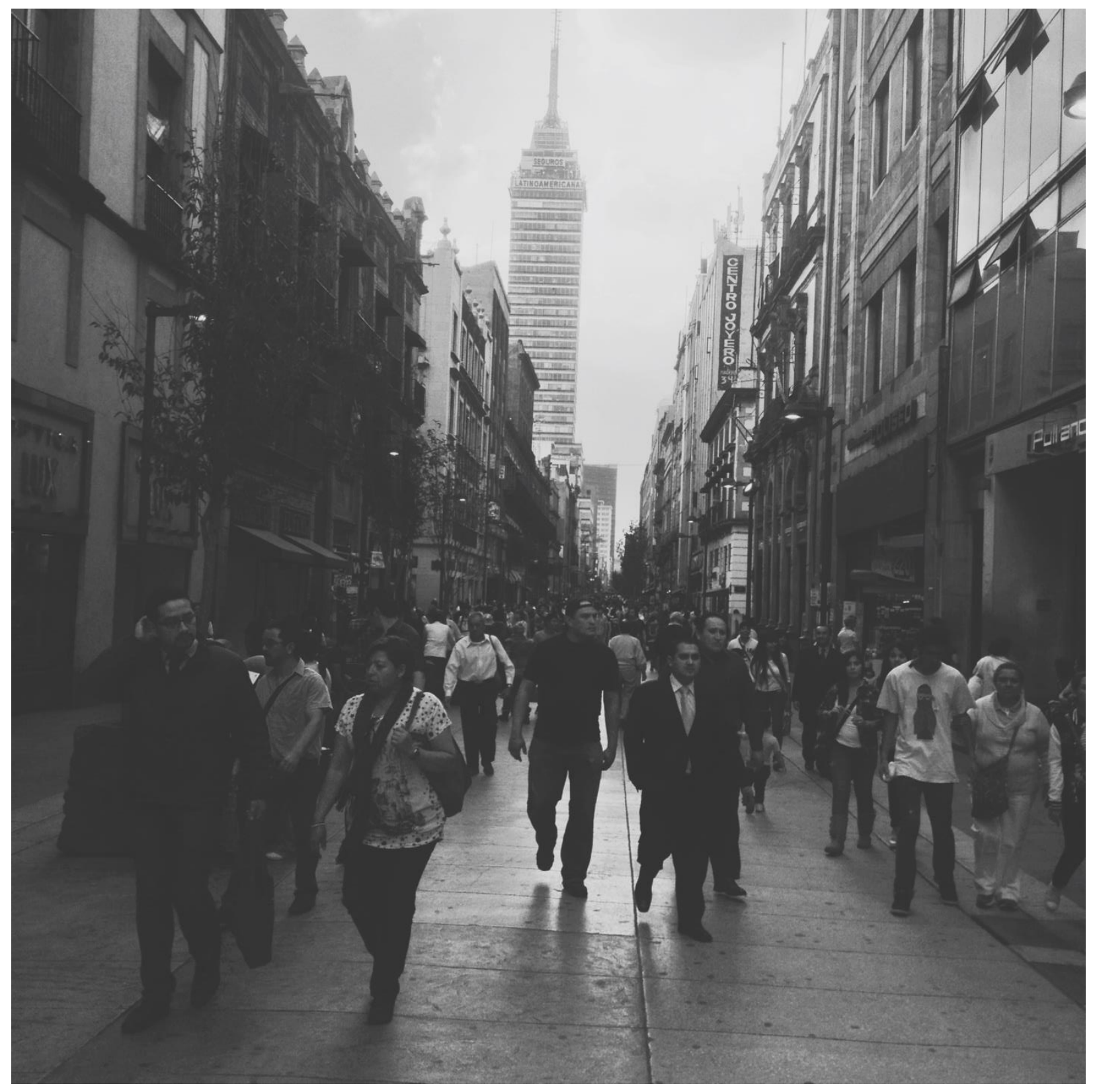

Photo credit: Ilan Sánchez @2016 